\title{
Effect of Boron and Sowing Dates on the Nutrients Concentration and Uptake in Wheat (Triticum aestivum)
}

\author{
M. S. Islam ${ }^{1 *}$ and M. Jahiruddin ${ }^{2}$ \\ ${ }^{1}$ Dept. Soil Science, Patuakhali Science \& Technology University, Bangladesh \\ ${ }^{2}$ Dept. Soil Science, Bangladesh Agricultural University, Mymensingh, Bangladesh \\ Corresponding author: msaifulpstu@yahoo.com
}

\begin{abstract}
The effect of boron and different dates of sowing on some wheat cultivars was studied at BAU farm during winter season of 2006-07. There were two boron treatments $\left(0\right.$ and $\left.1 \mathrm{~kg} \mathrm{~B} \mathrm{ha}^{-1}\right)$, three wheat cultivars (Prodip, Shatabdi and Sourav) and four sowing dates (18 November, 28 November, 08 December and 18 December, 2006). The experiment was conducted in a split-split plot design in the three replications. The grain samples were analyzed for $\mathrm{N}, \mathrm{P}, \mathrm{K}$ and $\mathrm{B}$, while the straw samples were analyzed for $\mathrm{P}, \mathrm{K}$ and $\mathrm{B}$ contents and uptake. Both $\mathrm{N}$ and B concentrations of grain were significantly increased by boron application.
\end{abstract}

Keywords: wheat variety, boron application, nutrients content and nutrient uptake by wheat

\section{Introduction}

Wheat, next to rice, is the most important cereal crop in Bangladesh. In Bangladesh about 0.84 million hectares of land is covered by wheat producing 0.976 million tons with an average yield of 1.16 t/ha (BBS, 2004). Late sowing coupled with boron deficiency might be the principal reason for low productivity of wheat in Bangladesh (Jahiruddin et al., 1992, Hossain et al., 1994 and Saifuzzaman, 1996). The increasing intensity of land use has resulted in a marked exhaustion of nutrients from the soils. For the large scale use of N, P and K fertilizers the other nutrients including boron are much taken up by plants and thus this causes nutrient depletion in soils. Several factors in the soil affect boron availability: $\mathrm{pH}$, texture, humidity and temperature (Gupta, 2002). Wheat response to boron depends on the cultivar and there are different responses to fertilization (Mahboodi et al., 2002, Torun et al., 2001). Each crop group also presents different genetic capability, which can be more or less responsive to fertilization as a result of active and passive mechanisms of boron absorption (Dordas and Brown, 2001) and the capability of stopping Alcohol-sugar-B complex through phloem (Bellaloui et al., 2003). These processes make the crop more adaptable to the environment. The intensive cropping with modern varieties and the nutrients leaching by monsoon rain have favoured the emergence of micronutrients in soils and crops of Bangladesh (Rahman, 1989; Mondal et al., 1992 and Jahiruddin et al., 1995) and among them, zinc and boron deficiencies are widespread. Gupta (1979) states that because of non-ionic nature, once boron is released from soil minerals, it can be leached out from the soil fairly rapidly. Wheat grown in a boron deficient soil exhibits a symptom of grain sterility (Rerkasem et al., 1989). Wheat varieties may differ in their sensitivity or tolerance to boron deficiency (Rerkasem and Jamjod, 1997; Kataki et al., 2001). Considering the above issues, the present study was undertaken-to evaluate the response of different varieties of wheat to boron application at different sowing dates for nutrient concentration and uptake; to evaluate the effect of boron, wheat varieties and sowing dates on the nutrient concentration and uptake by wheat and to identify the wheat variety that is tolerant or sensitive to boron application. 


\section{Materials and Methods}

The experiment was conducted in the field laboratory of the Department of Soil Science at Bangladesh Agricultural university (BAU) farm, Mymensingh, during November 2006 to April 2007. Characteristically, the soil was a silt loam having $\mathrm{pH} 6.74$, organic matter $1.97 \%$, total $\mathrm{N}$ $0.078 \%$, available P 9.92 ppm, available K 0.087 c mol kg ${ }^{-1}$, available $\mathrm{S} 12.35 \mathrm{ppm}$, available $\mathrm{Zn}$ $0.70 \mathrm{ppm}$ and available B $0.19 \mathrm{ppm}$. The test crop was wheat (Triticum aestivum).

The treatment consisted of (i) Boron level- $0 \mathrm{~kg}$ $\mathrm{B} \mathrm{ha}^{-1}, 1 \mathrm{~kg} \mathrm{~B} \mathrm{ha}^{-1}$ (BARC, 2005); (ii) Sowing date- November 18, 2006, November 28, 2006, December 08, 2006 and December 18, 2006; and (iii) Variety- Prodip, Shatabdi and Sourav. The experiment was laid out in a split-split plot design with a distribution of sowing dates to the main plots, varieties to the sub-plots and boron treatment to the sub-sub-plots. All the factors were replicated three times. The area of each unit plot was $12 \mathrm{~m}^{2}(3 \mathrm{~m} \times 4 \mathrm{~m})$. Data on grain-N, P, K, $\mathrm{B}$ and straw $\mathrm{P}, \mathrm{K}, \mathrm{B}$ concentration and uptake were recorded and analyzed statistically (Gomez and Gomez, 1984) by F-test to examine whether the treatment effects were significant. The mean comparisons of the treatments were evaluated by DMRT (Ducan's Multiple Range Test). The analysis of variance (ANOVA) for different parameters was done by a computer package programme "MSTATC".

\section{Results and Discussion}

\subsection{Impact of boron, wheat varieties and sowing dates on nutrients content and uptake}

\subsection{1. $N$ content and uptake}

The $\mathrm{N}$ concentration of grain was significantly increased after boron application to soil. The grain-N concentration in boron treated plot was $2.30 \%$ as against $1.78 \%$ in boron control plot (Table 1). The grain-N content did not vary among the varieties. Insignificant result was also found with sowing dates in respect of grain-N. Effect of boron on grain-N concentration was consistent over the varieties. There was a significant interaction of boron and sowing date on $\mathrm{N}$ content in wheat grain. It appeared that the response of grain-N to added boron was better for the 08 December $(2.07 \%)$ sowing than the other three sowing dates (Table 1). The $\mathrm{N}$ uptake by grain was significantly increased after boron application to soil. The grain-N uptake as obtained in B treated plot was $72.04 \mathrm{~kg} \mathrm{ha}^{-1}$ as against $46.64 \mathrm{~kg} \mathrm{ha}^{-1}$ in the $\mathrm{B}$ control. The highest grain-N uptake was recorded for 28 November sowing (74.01 kg ha ${ }^{-1}$, average of three years) and the lowest was recorded for 18 December sowing (41.39 $\mathrm{kg} \mathrm{ha}^{-1}$ ) (Table 4). The interaction effect of sowing date $\times$ variety $\times$ boron on the grain-N uptake was not significant (Table 6).

\subsection{2. $P$ content and uptake}

The $\mathrm{P}$ concentration of grain was significantly influenced by applied boron. The grain $\mathrm{P}$ concentration in boron treated plot was $0.275 \%$ as against $0.261 \%$ in boron control plot (Table 1 ). The grain-P content was comparatively higher in late sowing than in early sowing. The $\mathrm{P}$ concentration in wheat straw was not significantly affected by boron, wheat varieties or sowing dates. However the interaction effect of boron $\mathrm{x}$ variety and boron $\mathrm{x}$ sowing date was significant in terms of $\mathrm{P}$ concentration (Table 2 and 3). The grain-P uptake was significantly affected by boron treatments, varieties and sowing dates. The plants of B treated plots had grain-P uptake of $8.63 \mathrm{~kg}$ $\mathrm{ha}^{-1}$ as against $6.57 \mathrm{~kg} \mathrm{ha}^{-1}$ for $\mathrm{B}$ control plot. The 28 November sowing $\left(8.78 \mathrm{~kg} \mathrm{ha}^{-1}\right)$ recorded the highest grain-P uptake and the 18 December sowing did the lowest $\left(5.58 \mathrm{~kg} \mathrm{ha}^{-1}\right)$. The grain-P uptake by Sourav $\left(8.88 \mathrm{~kg} \mathrm{ha}^{-1}\right)$ was the highest and by Shatabdi $\left(6.89 \mathrm{~kg} \mathrm{ha}^{-1}\right)$ was the lowest. Like grain-P uptake, the straw-P uptake was significantly affected by sowing date and boron treatment but not by varieties (Table 4 ). Total $\mathrm{P}$ uptake (grain + straw) varied from 8.45 to 10.70 $\mathrm{kg} \mathrm{ha}^{-1}$ for B treatments, 6.84 to $10.99 \mathrm{~kg} \mathrm{ha}^{-1}$ for sowing dates and 8.79 to $10.80 \mathrm{~kg} \mathrm{ha}^{-1}$ for varieties (Table 5). The significant interaction effect of sowing date $\times$ variety $\times$ boron was found on the grain-P uptake (0.05) and straw-P uptake (0.05) (Table 6). 
Table 1. Effects of sowing date, variety, and boron on the N, $\mathrm{P}, \mathrm{K}$ and $\mathrm{B}$ concentration in grain and straw of wheat.

\begin{tabular}{|c|c|c|c|c|c|c|c|}
\hline \multirow{2}{*}{$\begin{array}{l}\text { Single } \\
\text { effect }\end{array}$} & \multicolumn{3}{|c|}{ Grain concentration } & \multicolumn{4}{|c|}{ Straw concentration } \\
\hline & $\begin{array}{l}\mathrm{N} \\
(\%)\end{array}$ & $\begin{array}{c}\mathrm{P} \\
(\%)\end{array}$ & $\begin{array}{c}\mathrm{K} \\
(\%)\end{array}$ & $\begin{array}{c}\mathrm{B} \\
\left(\mu \mathrm{g} \mathrm{g}^{-1}\right)\end{array}$ & $\begin{array}{c}\mathrm{P} \\
(\%)\end{array}$ & $\begin{array}{c}\mathrm{K} \\
(\%)\end{array}$ & $\begin{array}{c}\mathrm{B} \\
\left(\mu \mathrm{g} \mathrm{g}^{-1}\right)\end{array}$ \\
\hline \multicolumn{8}{|l|}{ Boron } \\
\hline $\mathrm{B}_{0}$ & 1.78 & 0.261 & 0.354 & 7.023 & 0.047 & 1.599 & 6.93 \\
\hline $\mathrm{B}_{1}$ & 2.30 & 0.275 & 0.372 & 13.08 & 0.049 & 1.589 & 16.83 \\
\hline $\operatorname{LSD}(\mathrm{P}=0.05)$ & 0.026 & 0.003 & 0.003 & 0.298 & 0.002 & 0.021 & 0.38 \\
\hline \multicolumn{8}{|l|}{ Variety } \\
\hline Prodip & 2.07 & 0.246 & 0.343 & 10.664 & 0.046 & 1.568 & 11.33 \\
\hline Shatabdi & 2.00 & 0.260 & 0.351 & 9.794 & 0.049 & 1.554 & 11.88 \\
\hline Sourav & 2.06 & 0.299 & 0.397 & 9.711 & 0.050 & 1.660 & 12.42 \\
\hline $\operatorname{LSD}(\mathrm{P}=0.05$ & 5) 0.037 & 0.013 & 0.006 & 0.194 & 0.003 & 0.013 & 0.37 \\
\hline \multicolumn{8}{|l|}{ Sowing date } \\
\hline Nov. 18 & 2.06 & 0.252 & 0.373 & 11.423 & 0.043 & 1.673 & 13.84 \\
\hline Nov. 28 & 2.02 & 0.248 & 0.343 & 10.914 & 0.048 & 1.703 & 11.78 \\
\hline Dec. 08 & 2.07 & 0.301 & 0.384 & 8.883 & 0.056 & 1.709 & 11.60 \\
\hline Dec. 18 & 2.02 & 0.276 & 0.352 & 9.005 & 0.049 & 1.291 & 10.21 \\
\hline $\operatorname{LSD}(\mathrm{P}=0.05)$ & 0.022 & 0.14 & 0.008 & 0.313 & 0.003 & 0.033 & 0.49 \\
\hline
\end{tabular}

Table 2. Interaction effects of boron and variety on the grain and straw nutrients content of wheat.

\begin{tabular}{lccccccc}
\hline $\begin{array}{l}\text { Interaction } \\
\text { (Boron×var }\end{array}$ & \multicolumn{3}{c}{ Grain nutrients concentration } & \multicolumn{2}{c}{ Straw nutrients concentration } \\
\cline { 2 - 8 } iety) & $\mathrm{N}(\%)$ & $\mathrm{P}(\%)$ & $\mathrm{K}(\%)$ & $\mathrm{B}(\mu \mathrm{g} \mathrm{g})$ & $\mathrm{P}(\%)$ & $\mathrm{K}(\%)$ & $\mathrm{B}\left(\mu \mathrm{g} \mathrm{g}^{-1}\right)$ \\
\hline $\mathrm{B}_{0} \mathrm{~V}_{1}$ & 1.81 & 0.240 & 0.333 & 7.373 & 0.049 & 1.605 & 6.33 \\
$\mathrm{~B}_{1} \mathrm{~V}_{1}$ & 2.32 & 0.252 & 0.353 & 13.954 & 0.042 & 1.531 & 16.34 \\
$\mathrm{~B}_{0} \mathrm{~V}_{2}$ & 1.71 & 0.260 & 0.343 & 5.556 & 0.047 & 1.508 & 7.25 \\
$\mathrm{~B}_{1} \mathrm{~V}_{2}$ & 2.29 & 0.260 & 0.358 & 13.031 & 0.051 & 1.600 & 16.51 \\
$\mathrm{~B}_{0} \mathrm{~V}_{3}$ & 1.82 & 0.284 & 0.388 & 7.141 & 0.045 & 1.683 & 7.20 \\
$\mathrm{~B}_{1} \mathrm{~V}_{3}$ & 2.30 & 0.314 & 0.405 & 12.281 & 0.054 & 1.637 & 17.64 \\
\hline $\mathrm{LSD}(\mathrm{P}=0.05)$ & $\mathrm{NS}$ & 0.023 & $\mathrm{NS}$ & $\mathrm{NS}$ & 0.023 & $\mathrm{NS}$ & $\mathrm{NS}$ \\
\hline
\end{tabular}

Table 3. Interaction effects of boron and sowing dates on the grain and straw nutrients content of wheat.

\begin{tabular}{|c|c|c|c|c|c|c|c|}
\hline \multirow{2}{*}{$\begin{array}{l}\text { Interaction } \\
\text { (Boron } \times \text { So } \\
\text { wing dates) }\end{array}$} & \multicolumn{4}{|c|}{ Grain nutrients concentration } & \multicolumn{3}{|c|}{ Straw nutrients concentration } \\
\hline & $\mathrm{N}(\%)$ & $\mathrm{P}(\%)$ & $\mathrm{K}(\%)$ & $\mathrm{B}\left(\mu \mathrm{g} \mathrm{g}^{-1}\right)$ & $\mathrm{P}(\%)$ & $\mathrm{K}(\%)$ & $\mathrm{B}\left(\mu \mathrm{g} \mathrm{g}^{-1}\right)$ \\
\hline $\mathrm{B}_{0} \mathrm{~S}_{1}$ & 1.83 & 0.239 & 0.363 & 7.942 & 0.045 & 1.663 & 7.61 \\
\hline $\mathrm{B}_{1} \mathrm{~S}_{1}$ & 2.29 & 0.264 & 0.383 & 14.904 & 0.041 & 1.683 & 20.07 \\
\hline $\mathrm{B}_{0} \mathrm{~S}_{2}$ & 1.83 & 0.240 & 0.353 & 7.850 & 0.052 & 1.732 & 7.02 \\
\hline $\mathrm{B}_{1} \mathrm{~S}_{2}$ & 2.20 & 0.251 & 0.333 & 13.977 & 0.043 & 1.674 & 16.54 \\
\hline $\mathrm{B}_{0} \mathrm{~S}_{3}$ & 1.79 & 0.282 & 0.350 & 5.574 & 0.049 & 1.659 & 6.70 \\
\hline $\mathrm{B}_{1} \mathrm{~S}_{3}$ & 2.35 & 0.320 & 0.417 & 12.191 & 0.063 & 1.758 & 16.65 \\
\hline $\mathrm{B}_{0} \mathrm{~S}_{4}$ & 1.67 & 0.284 & 0.351 & 6.727 & 0.043 & 1.341 & 6.38 \\
\hline $\mathrm{B}_{1} \mathrm{~S}_{4}$ & 2.37 & 0.267 & 0.353 & 11.282 & 0.051 & 1.241 & 14.03 \\
\hline $\operatorname{LSD}(\mathrm{P}=0.05)$ & 2.65 & 0.23 & 0.001 & $\mathrm{NS}$ & 0.003 & NS & 3.61 \\
\hline
\end{tabular}




\subsection{3. $K$ content and uptake}

The $\mathrm{K}$ concentration of grain was significantly affected by boron treatment, crop variety and sowing dates. The grain-K concentration was the highest in Sourav (0.397 \%) and lowest in Prodip $(0.343 \%)$ (Table1). The interaction effect of boron $\times$ variety was non-significant while it was significant for grain-K in case of boron $\times$ sowing date interaction (Table 2 and 3). The highest $\mathrm{K}$ concentration in straw was observed with Sourav $(1.66 \%)$ and lowest with Shatabdi $(1.55 \%)$. The straw-K was the highest for 08 December $(1.71$ $\%)$ and lowest for 18 December sowings (1.29 $\%)$ (Table1). The interaction effect of boron $x$ variety and boron $\times$ sowing date was not significant in respect of $\mathrm{K}$ concentration of wheat straw (Table 2 and 3 ). The grain-K as well as the straw-K uptake was significantly influenced by boron treatment, varieties and sowing dates. The result of 28 November sowing was significantly higher than that of the other dates. The plants of $\mathrm{B}$ treated plots had grain-K uptake of $11.64 \mathrm{~kg} \mathrm{ha}^{-1}$ as against $9.14 \mathrm{~kg} \mathrm{ha}^{-1}$ for B control plot. The grain-K uptake was the highest in Sourav (11.90 kg ha $\left.{ }^{-1}\right)$ and lowest in Shatabdi $\left(9.37 \mathrm{~kg} \mathrm{ha}^{-1}\right)$, while the straw-K uptake was higher in Shatabdi $\left(73.40 \mathrm{~kg} \mathrm{ha}^{-1}\right)$ and lower in Prodip (58.13 kg ha ${ }^{-1}$ ) (Table 4). Combing grain and straw uptake of $\mathrm{K}$, the total uptake ranged from $72.73-80.00 \mathrm{~kg} \mathrm{ha}^{-1}, 41.03-91.90$ $\mathrm{kg} \mathrm{ha}{ }^{-1}$ and $68.01-82.76 \mathrm{~kg} \mathrm{ha}^{-1}$ for the B treatments, sowing dates and wheat varieties, respectively (Table 5). The interaction effects of sowing date $\times$ variety $\times$ boron were significant in respect of grain-K uptake but in case of straw-K uptake, the interaction effects of sowing date $\times$ variety $\times$ boron were not significant (Table 6).

\subsubsection{B content and uptake}

Boron treatment produced, on an average, 13.08 $\mu \mathrm{g} \mathrm{g}^{-1}$ grain-B in wheat grain as against $7.023 \mu \mathrm{g}$ $\mathrm{g}^{-1}$ grain-B recorded in the control (Table1). The $\mathrm{B}$ concentration of grain was also affected by variety and sowing date. The highest grain-B was found in Prodip (10.66 $\left.\mu \mathrm{g} \mathrm{g}^{-1}\right)$ and lowest in Sourav $\left(9.71 \mu \mathrm{g} \mathrm{g}^{-1}\right)$. On the other hand, the B concentration was higher in the first sowing (November 18) and then declined steadily with delay in sowing (Table1). This result indicates that sowing date on 18 November was the best for B concentration of wheat grain. There was no significant interaction between boron and variety in respect of grain-B content (Table 2). There was a significant effect of added boron and sowing dates on straw boron content. Again, the interaction effect of boron $\times$ sowing dates was significant in respect of straw-B content (Table 3). The grain-B uptake by wheat grain was significantly influenced by boron treatment and sowing dates but not by variety. The plants of B treated plots had grain-B uptake of $41.7 \mathrm{~g}$ $\mathrm{ha}^{-1}$, as against $19.8 \mathrm{~g} \mathrm{ha}^{-1}$ for $\mathrm{B}$ control plot. The grain-B uptake as recorded for 18 November sowing was the highest $\left(41.00 \mathrm{~g} \mathrm{ha}^{-1}\right)$ and was the lowest for 18 December sowing (18.50 $\mathrm{g}$ ha $\left.{ }^{1}\right)$ (Table 4). The plants of B treated plots had straw-B uptake of $72.60 \mathrm{~g} \mathrm{ha}^{-1}$, as against $28.0 \mathrm{~g}$ $\mathrm{ha}^{-1}$ for B control plot. The straw-B uptake was the highest for Shatabdi $\left(55.4 \mathrm{~g} \mathrm{ha}^{-1}\right)$ and lowest for Prodip $\left(44 \mathrm{~g} \mathrm{ha}^{-1}\right)$. The straw-B uptake as recorded for 18 November sowing was the highest $\left(66.40 \mathrm{~g} \mathrm{ha}^{-1}\right)$ and was the lowest for 18 December sowing (28.20 $\mathrm{g} \mathrm{ha}^{-1}$ ) (Table 4). Total B uptake by wheat for different sowing dates was 46.70-107.5 $\mathrm{g} \mathrm{ha}^{-1}$ and for varieties 75.70$85.30 \mathrm{~g} \mathrm{ha}^{-1}$. The treatments with 0 and $1 \mathrm{~kg} \mathrm{~B}$ $\mathrm{ha}^{-1}$ had the total B uptake by plant (grain + straw) of 47.80 and $114.30 \mathrm{~g} \mathrm{ha}^{-1}$, respectively (Table 5). The interaction effects of sowing date $x$ variety $\times$ boron were not significant in respect of both grain-B and straw-B uptake (Table 6).

\subsection{Correlation of boron with other nutrients}

The $\mathrm{N}$ concentration of grain was significantly correlated with the $\mathrm{B}$ concentration in grain $(\mathrm{r}=0.80 ; \mathrm{P}<0.001)$, which indicates that boron had helped protein synthesis (protein $=\% \mathrm{~N} \times 5.85$ ) and the plant maintains a definite N-B ratio in its tissues. There was a significant correlation between grain-B and straw-B concentrations $(\mathrm{r}=0.872 ; \quad \mathrm{P}<\mathrm{0.001})$. As expected, the relationship between grain-N and straw-B was significant ( $r=0.817)$. Significant correlation was also found between $\mathrm{P}$ and $\mathrm{K}$ concentrations of grain. The correlation coefficient ( $r$ value) for the other cases was not significant (Table 7). 
Table 4. Effects of sowing date, variety, and boron on the N, P, K and B uptake by grain and straw of wheat.

\begin{tabular}{|c|c|c|c|c|c|c|c|}
\hline \multirow[t]{2}{*}{ Single effect } & \multicolumn{4}{|c|}{ Grain uptake } & \multicolumn{3}{|c|}{ Straw uptake } \\
\hline & $\begin{array}{c}\mathrm{N} \\
\left(\mathrm{kg} \mathrm{ha}^{-1}\right)\end{array}$ & $\begin{array}{c}\mathrm{P} \\
\left(\mathrm{kg} \mathrm{ha}^{-1}\right)\end{array}$ & $\begin{array}{c}\mathrm{K} \\
\left(\mathrm{kg} \mathrm{ha}^{-1}\right)\end{array}$ & $\begin{array}{c}\mathrm{B} \\
\left(\mathrm{g} \mathrm{ha}^{-1}\right)\end{array}$ & $\begin{array}{c}\mathrm{P} \\
\left(\mathrm{kg} \mathrm{ha}^{-1}\right)\end{array}$ & $\begin{array}{c}\mathrm{K} \\
\left(\mathrm{kg} \mathrm{ha}^{-1}\right)\end{array}$ & $\begin{array}{c}\text { B } \\
\left(\mathrm{g} \mathrm{ha}^{-1}\right)\end{array}$ \\
\hline \multicolumn{8}{|l|}{ Boron } \\
\hline $\mathrm{B}_{0}$ & 46.64 & 6.57 & 9.14 & 19.8 & 1.88 & 63.58 & 28.00 \\
\hline $\mathrm{B}_{1}$ & 72.04 & 8.63 & 11.64 & 41.7 & 2.07 & 68.39 & 72.60 \\
\hline $\operatorname{LSD}(\mathrm{P}=0.05)$ & 0.001 & 0.001 & 0.001 & 0.001 & NS & 1.5 & 0.001 \\
\hline \multicolumn{8}{|l|}{ Variety } \\
\hline Prodip & 60.56 & 7.04 & 9.91 & 31.7 & 1.75 & 58.13 & 44.00 \\
\hline Shatabdi & 55.66 & 6.89 & 9.37 & 29.9 & 2.24 & 73.40 & 55.40 \\
\hline Sourav & 61.80 & 8.88 & 11.90 & 30.7 & 1.93 & 66.43 & 51.5 \\
\hline $\operatorname{LSD}(\mathrm{P}=0.05)$ & NS & 0.50 & 1.30 & NS & NS & 0.80 & 0.50 \\
\hline \multicolumn{8}{|l|}{ Sowing date } \\
\hline Nov. 18 & 67.94 & 8.30 & 12.27 & 41.00 & 1.98 & 77.24 & 66.40 \\
\hline Nov. 28 & 74.01 & 8.78 & 12.28 & 39.90 & 2.21 & 79.62 & 56.00 \\
\hline Dec. 08 & 54.02 & 7.75 & 9.89 & 23.70 & 2.44 & 73.14 & 50.50 \\
\hline Dec. 18 & 41.39 & 5.58 & 7.13 & 18.50 & 1.27 & 33.93 & 28.20 \\
\hline $\operatorname{LSD}(\mathrm{P}=0.05)$ & 0.03 & 1.9 & 0.10 & 0.09 & 0.30 & 0.001 & 0.02 \\
\hline
\end{tabular}

Table 5. Single effect of sowing date, variety and boron on total uptake of $\mathrm{P} K$ and $\mathrm{B}$ by grain and straw of wheat.

\begin{tabular}{|c|c|c|c|}
\hline Single effect & $\mathrm{P} \quad\left(\mathrm{kg} \mathrm{ha}^{-1}\right)$ & $\mathrm{K} \quad\left(\mathrm{kg} \mathrm{ha}^{-1}\right)$ & $\left(\mathrm{g} \mathrm{ha}^{-1}\right)$ \\
\hline \multicolumn{4}{|l|}{ Boron } \\
\hline $\mathrm{B}_{0}$ & 8.45 & \multirow[t]{2}{*}{72.73} & 47.80 \\
\hline $\mathrm{B}_{1}$ & 10.70 & & 114.30 \\
\hline \multicolumn{4}{|l|}{ Variety } \\
\hline Prodip & 8.79 & 68.01 & 75.70 \\
\hline Shatabdi & 9.13 & 82.76 & 85.30 \\
\hline Sourav & 10.80 & 78.33 & 82.20 \\
\hline \multicolumn{4}{|l|}{ Sowing dates } \\
\hline Nov.18 & 10.28 & 89.91 & 107.50 \\
\hline Nov.28 & 10.99 & 91.90 & 95.90 \\
\hline Dec. 08 & 10.19 & 83.02 & 74.10 \\
\hline Dec. 18 & 6.84 & 41.03 & 46.70 \\
\hline \multicolumn{2}{|c|}{$\begin{array}{l}\text { 4. Conclusions } \\
\text { The result indicates that the } \mathrm{N} \text { concentration of } \\
\text { grain was significantly influenced by applied } \\
\text { boron. On the other hand, variety and sowing date } \\
\text { had no significant effect on grain-N content. Like } \\
\text { grain-N, the grain-P, grain-K and grain-B contents } \\
\text { were significantly improved after boron } \\
\text { application. The straw-B concentration was also } \\
\text { significantly influenced by boron treatment, but the } \\
\text { straw-P and straw-K were not affected by this }\end{array}$} & \multicolumn{2}{|c|}{$\begin{array}{l}\text { treatment. The } \mathrm{N} \text { uptake by grain and straw was } \\
\text { significantly influenced by boron treatment, variety } \\
\text { and sowing date. Another benefit of boron } \\
\text { application was that it had significant and positive } \\
\text { effect on the grain } \mathrm{N} \text { concentration indicating that } \\
\text { boron helped protein synthesis. The overall result } \\
\text { indicates that wheat seeds need to be sown between } \\
\text { end of November and beginning of December and } \\
\text { the varieties to be chosen could be Sourav or } \\
\text { Prodip for the areas under AEZ 9. }\end{array}$} \\
\hline
\end{tabular}


Table 6. Interaction effect of sowing date, variety and boron on grain and straw nutrient uptake of wheat.

\begin{tabular}{|c|c|c|c|c|c|c|c|c|c|}
\hline \multirow{2}{*}{\multicolumn{3}{|c|}{$\begin{array}{l}\text { Interaction effect } \\
\text { Sowing date } \times \text { Variety } \times \\
\text { Boron }\end{array}$}} & \multicolumn{4}{|c|}{ Grain uptake } & \multicolumn{3}{|c|}{ Straw uptake } \\
\hline & & & $\begin{array}{c}\mathrm{N} \\
\left(\mathrm{kg} \mathrm{ha}^{-1}\right)\end{array}$ & $\begin{array}{c}\mathrm{P} \\
\left(\mathrm{kg} \mathrm{ha}^{-1}\right)\end{array}$ & $\begin{array}{c}\mathrm{K} \\
\left(\mathrm{kg} \mathrm{ha}^{-1}\right)\end{array}$ & $\begin{array}{c}\text { B } \\
\left(\mathrm{g} \mathrm{ha}^{-1}\right)\end{array}$ & $\begin{array}{c}\mathrm{P} \\
\left(\mathrm{kg} \mathrm{ha}^{-1}\right)\end{array}$ & $\begin{array}{c}\mathrm{K} \\
\left(\mathrm{kg} \mathrm{ha}^{-1}\right)\end{array}$ & $\begin{array}{c}\mathrm{B} \\
\left(\mathrm{g} \mathrm{ha}^{-1}\right)\end{array}$ \\
\hline \multirow{6}{*}{ Nov. 18} & Prodip & $\mathrm{B}_{0}$ & 56.50 & 6.42 & 9.60 & 21.70 & 1.98 & 56.47 & 28.50 \\
\hline & Prodip & $\mathrm{B}_{1}$ & 84.60 & 8.78 & 13.55 & 54.80 & 1.40 & 68.73 & 76.40 \\
\hline & Shatabdi & $\mathrm{B}_{0}$ & 41.02 & 6.34 & 8.49 & 37.80 & 1.98 & 90.50 & 47.30 \\
\hline & Shatabdi & $\mathrm{B}_{1}$ & 73.25 & 7.56 & 11.00 & 45.70 & 2.98 & 90.03 & 114.70 \\
\hline & Sourav & $\mathrm{B}_{0}$ & 61.96 & 7.94 & 13.67 & 25.20 & 1.83 & 71.63 & 27.80 \\
\hline & Sourav & $\mathrm{B}_{1}$ & 90.30 & 12.75 & 17.30 & 60.01 & 1.69 & 86.10 & 103.70 \\
\hline \multirow{6}{*}{ Nov. 28} & Prodip & $\mathrm{B}_{0}$ & 62.71 & 7.58 & 11.54 & 25.30 & 2.88 & 73.96 & 30.70 \\
\hline & Prodip & $\mathrm{B}_{1}$ & 85.56 & 8.19 & 12.32 & 53.50 & 1.89 & 60.93 & 90.70 \\
\hline & Shatabdi & $\mathrm{B}_{0}$ & 65.18 & 6.72 & 11.18 & 23.90 & 2.08 & 80.03 & 35.10 \\
\hline & Shatabdi & $\mathrm{B}_{1}$ & 93.51 & 10.71 & 13.75 & 56.90 & 1.87 & 95.57 & 68.00 \\
\hline & Sourav & $\mathrm{B}_{0}$ & 60.64 & 9.56 & 12.66 & 30.10 & 2.23 & 84.17 & 34.30 \\
\hline & Sourav & $\mathrm{B}_{1}$ & 76.49 & 9.91 & 12.24 & 50.10 & 2.34 & 83.07 & 77.20 \\
\hline \multirow{6}{*}{ Dec. 08} & Prodip & $\mathrm{B}_{0}$ & 47.14 & 6.78 & 8.41 & 17.10 & 1.80 & 64.03 & 23.10 \\
\hline & Prodip & $\mathrm{B}_{1}$ & 74.61 & 9.88 & 11.45 & 43.80 & 2.28 & 67.93 & 60.60 \\
\hline & Shatabdi & $\mathrm{B}_{0}$ & 30.53 & 5.35 & 6.19 & 7.70 & 3.21 & 78.70 & 33.80 \\
\hline & Shatabdi & $\mathrm{B}_{1}$ & 55.54 & 6.53 & 9.56 & 26.80 & 3.16 & 87.50 & 82.30 \\
\hline & Sourav & $\mathrm{B}_{0}$ & 43.79 & 6.68 & 8.87 & 13.40 & 1.42 & 67.27 & 28.20 \\
\hline & Sourav & $\mathrm{B}_{1}$ & 72.53 & 11.29 & 14.87 & 33.40 & 2.77 & 73.40 & 74.70 \\
\hline \multirow{6}{*}{ Dec. 18} & Prodip & $\mathrm{B}_{0}$ & 27.11 & 4.14 & 5.50 & 12.90 & 0.82 & 36.53 & 11.10 \\
\hline & Prodip & $\mathrm{B}_{1}$ & 46.26 & 4.55 & 6.86 & 24.40 & 1.00 & 36.43 & 30.50 \\
\hline & Shatabdi & $\mathrm{B}_{0}$ & 33.17 & 5.70 & 6.86 & 12.00 & 1.23 & 31.93 & 17.20 \\
\hline & Shatabdi & $\mathrm{B}_{1}$ & 53.07 & 6.17 & 7.93 & 28.50 & 1.42 & 32.90 & 44.70 \\
\hline & Sourav & $\mathrm{B}_{0}$ & 29.98 & 5.64 & 6.74 & 10.90 & 1.07 & 27.73 & 18.50 \\
\hline & Sourav & $\mathrm{B}_{1}$ & 58.73 & 7.26 & 8.86 & 22.40 & 2.05 & 38.03 & 47.20 \\
\hline \multicolumn{3}{|c|}{ Level of significance } & NS & 0.05 & 0.05 & NS & 0.05 & NS & NS \\
\hline
\end{tabular}


Table 7. Correlation matrix among the grain and straw nutrients concentrations of wheat $(n=24)$

\begin{tabular}{|c|c|c|c|c|c|c|c|}
\hline Variables & $\begin{array}{c}\text { Grain N } \\
(\%)\end{array}$ & $\begin{array}{c}\text { Grain P } \\
(\%)\end{array}$ & $\begin{array}{c}\text { Straw P } \\
(\%)\end{array}$ & $\begin{array}{c}\text { Grain K } \\
(\%)\end{array}$ & $\begin{array}{c}\text { Straw K } \\
(\%)\end{array}$ & $\begin{array}{l}\text { Grain B } \\
\left(\mu g^{-1}\right)\end{array}$ & $\begin{array}{l}\text { Straw B } \\
\left(\mu g g^{-1}\right)\end{array}$ \\
\hline Grain N (\%) & 1 & & & & & & \\
\hline Grain P (\%) & 0.172 & 1 & & & & & \\
\hline Straw P (\%) & 0.210 & 0.355 & 1 & & & & \\
\hline Grain K (\%) & 0.319 & $0.611 * *$ & 0.301 & 1 & & & \\
\hline Straw K $(\%)$ & -0.027 & -0.011 & -0.019 & 0.350 & 1 & & \\
\hline Grain B $\left(\mu \mathrm{g} \mathrm{g}^{-1}\right)$ & $0.801 * * *$ & 0.015 & -0.164 & 0.120 & 0.165 & 1 & \\
\hline
\end{tabular}





\section{References}

BARC (Bangladesh Agricultural Research Council) 2005. Fertilizer Recommendation Guide-2005. Soil Pub. No. 45. Farmgate, Dhaka. 169 p.

BBS (Bangladesh Bureau of Statistics). 2004. Statistical Yearbook of Bangladesh. Bangladesh Bur. Stat. Ministry of Planning. Govt. of the People's Republic of Bangladesh. Dhaka. $130 \mathrm{p}$.

Bellaloui, N., Yadavc, R.C., Chern, M.S., Hu, H., Gillen, A.M., Greve, C., Dandekan, A.M., Ronald, P.C. and Brown, P.C. 2003. Transgenically enhanced sorbitol synthesis facilitates phloem-boron mobility in rice. Physiologia Plantarum, 117: 79-84.

Dordas, C. and Brown, P.H. 2001. Evidence mediated channel in transport of boric acid in Squash. Plant and Soil, 235: 95-103.

Gomez, A. K. and Gomez, A. A (1984). Statistical Procedure for Agricultural Research. Int. Rice Res. Inst., John Wily and Sons. New York, Chickester, Brisbane, Toronto, Singapore, p 680.

Gupta, U.C. 1979. Boron nutrition of crops. Advanced Agronomy, 31: 273-307.

Gupta, U.C. 2002. Boron and its role in crop production. Boca Ratow: Crop research center Press, p 237.

Hossain, M.A., Jahiruddin, M., Hoque, M.S. and Ali, M.I. 1994. Effect of genotype and sowing date on the response to Boron in wheat. Pakistan Journal of Scientific and Industrial Research, 37(10): 432-435.

Jahiruddin, M., Abedin, M.J. and Ahmed, M.U.1992. Boron deficiency a major factor for grain sterility in wheat. $4^{\text {th }}$ Proc. of the inter-congress conference of commission, December 1-3, pp 85-92.

Jahiruddin, M., Ali, M.S., Hossain, M.A., Ahmed, M.U. and Hoque, M.M. 1995. Effect of boron on grain set, yield and some other parameters of wheat cultivars. Bangladesh Journal of Agricultural Science, 22(1): 179-184.
Kataki, P.K., Upreti, H.K. and Bhatta, M.R. 2001. Soil boron deficiency induced wheat sterility in Nepal: response to boron and nitrogen application. Journal of New Seeds, 3(4): 23-39.

Mahaboodi, H., Yucel, M. and Oktem, H.A. 2002. Nitrate redutase and glutamate dehydrogenase activities of resistant and sensitive cultivars of wheat and barley under boron toxicity. Journal of Plant Nutrition, 25: 1829-1837.

Mondal, M.H.R., Jahiruddin, M., Rahman, M.M. and Hashem, M.A. 1992. An investigation on nutrient requirements for BR-11 rice in Old Brahmaputra Floodplain soils. Bangladesh Journal of Crop Science, 2: 22-31.

Rahman, S. 1989. Influence of Different Nutrients on Grain Formation in Wheat, $M$. Sc. Thesis, Department of Soil Science, Bangladesh Agricultural University, Mymensingh, p 38.

Rerkasem, B., Saunders, D.A. and Dell, B. 1989. Grain set failure and boron deficiency in wheat in Thailand. Journal of Agriculture (Chiangmai Univ.) 5:1-10.

Rerkasem, B. and Jamjod, S. 1997. Genotypic variation in plant response to low boron and implications for plant breeding. Plant and Soil 193, 169-180.

Saifuzzaman, M. 1996. Influence of seeding date, genotype and boron on sterility of wheat in Bangladesh. Proceedings of a workshop. 1821 September, 1995 held at Lumle Agriculture and Research center, Pokhara, Nepal, pp 46-50.

Torun, A., Gultekin, I, Kalayei, M.,Ylmaz, A., Elker, S. and Cakmak, I. 2001. Effects of zinc fertilization on grain yield and shoot concentrations of zinc, boron, on phosphorus of 25 wheat cultivars grown on a zinc deficient and boron toxic soil. Journal of Plant Nutrition, 24: 1817-1829. 